\title{
Tetra Kiral ve İçe Girintili Çarpışma Kutularının Çarpışma Performanslarının İncelenmesi
}

\author{
Cüneyt Aktaş ${ }^{1 *}$, Prof.Dr. Erdem Acar ${ }^{2}$, Prof.Dr. Mehmet Ali Güler ${ }^{3,4}$, Doç.Dr. Murat Altın ${ }^{5}$ \\ 1* TOBB ETU, Mühendislk Fakültesi, Makine Mühendisliği Bölümü, Ankara, Türkiye, (ORCID: 0000-0002-3971-3257), c.aktas@etu.edu.tr \\ 2 TOBB ETU, Mühendislk Fakültesi, Makine Mühendisliği Bölümü, Ankara, Türkiye (ORCID: 0000-0002-3661-5563), acar@etu.edu.tr \\ ${ }^{3}$ College of Engineering and Technology, American University of the Middle East, Kuwait, mehmet.guler@aum.edu.kw \\ ${ }^{4}$ TOBB ETU, Mühendislk Fakültesi, Makine Mühendisliği Bölümü, Ankara, Türkiye (ORCID: 0000-0002-1159-556X), mguler@etu.edu.tr \\ ${ }^{5}$ Gazi Üniversitesi, Teknoloji Fakültesi, Otomotiv Mühendisliği Bölümü, Ankara, Türkiye (ORCID: 0000-0002-2404-2614), maltin@gazi.edu.tr
}

(2nd International Conference on Access to Recent Advances in Engineering and Digitalization (ARACONF)-10-12 March 2021)

(DOI: 10.31590/ejosat.901494)

ATIF/REFERENCE: Aktaş, C., Acar, E., Güler, M.A. \& Altın, M. (2021). Tetra Kiral ve İçe Girintili Çarpışma Kutularının Çarpışma Performanslarının İncelenemesi. Avrupa Bilim ve Teknoloji Dergisi, (24), 161-168.

$\ddot{O} \mathbf{z}$

Çarpışma kutuları; taşıtlarda kullanılan, kaza anında ortaya çıkan enerjiyi sönümleyen pasif güvenlik sistemleridir. Bu enerji sönümleme kabiliyeti sayesinde yolcuların çarpışmadan mümkün olduğu kadar az etkilenmesini sağlar. Bu çalışmada, negatif Poisson oranına sahip yapılardan olan "Tetra Kiral" ve "İçe Girintili" tasarımlar ele alınmış, bu tasarımlardan silindir ve kare kesite sahip çarpışma kutuları oluşturularak çarpışma performansları incelenmiştir. Çalışma kapsamında öncelikle, çarpışma kutusu üretiminde kullanılacak olan 6061-T6 alüminyum malzemenin özeliklerini belirlemek için çekme testleri yapılmışır. Ardından, çarpışma kutularının performanslarını belirlemek için LS-DYNA yazılımı ile sonlu elemanlar analizleri yapılmıştır. Elde edilen analiz sonuçlarına göre; kare kesite sahip içe girintili çarpışma kutusunun en yüksek özgül enerji emilimine sahip olduğu, kare kesite sahip tetra kiral çarpışma kutusunun ise en küçük tepe ezilme kuvveti değerine ve en yüksek ezilme kuvveti verimi değerine sahip olduğu gözlenmiştir.

Anahtar Kelimeler: Çarpışma kutusu, negatif Poisson oranı, tetra kiral yapı, içe girintili yapı, sonlu elemanlar analizi.

\section{An Investigation of the Crashworthiness Performance of Tetra Chiral and Re-entrant Crush Boxes}

\begin{abstract}
Crash boxes are passive safety systems that are used in vehicles to absorb the energy generated in the event of an accident. Due to their energy absorption capability, they ensure that passengers are affected as little as possible. In this study, "Tetra Chiral" and "Re-entrant" designs, which are structures with negative Poisson's ratio, are discussed, collision performances are investigated by forming collision boxes with cylindrical and square sections from these designs. In this study, first tensile tests are carried out to determine the properties of 6061-T6 aluminum material to be used in crash box production. Then, finite element analyses are performed by using LS-DYNA software to determine the performances of the crash boxes. The results shows that the re-entrant crush box with square cross section has the highest specific energy absorption, while the tetra chiral crush box with square cross-section has the smallest peak crushing force value and the highest crushing force efficiency value.
\end{abstract}

Keywords: Crash box, negative Poisson's ratio, tetra chiral structure, re-entrant structure, finite element analysis.

*Sorumlu Yazar: c.aktas@etu.edu.tr 


\section{Giriş}

Otomobil, icadıyla birlikte günlük yaşantıda önemli bir yer almış ve insan yaşamını kolaylaştırdığı için günümüzün vazgeçilmez ulaşım araçlarından biri olmuştur. Otomobil kazalarının büyük bir kısmı önden çarpma şeklinde gerçekleşmektedir. Bu durumun bir sonucu olarak tasarımcılar, araçlara çarpışma kutusu adı verilen bir yapıyı entegre etmiştir. $\mathrm{Bu}$ yapı sayesinde hayati tehlikeye neden olan kazaların önüne geçmek ve yüksek maliyetli zararları ortadan kaldırmak hedeflenmiştir. Otomobillerde ön tamponda bulunan çarpışma kutuları, kaza anında meydana gelen çarpışma etkisinden kaynaklanan enerjiyi sönümleyerek yolcu ve araç ekipmanlarını korumaktadir.

Çarpışma sırasında oluşan ezilme kuvvetleri, çarpışma kutusu tasarımda dikkate alınması gereken önemli parametrelerden biridir. Bir çarpışma kutusu için, emilen enerjiyi en üst düzeye çıkartmak yeterli olmamak ile birlikte çarpışma sonucu ortaya çıkan tepe kuvvetlerini de minimum seviyeye düşürmek çok önemlidir. $\mathrm{Bu}$ nedenle, çarpışma kutusu verimliliğinin belirlenmesi için çarpışma performansı metrikleri detaylı bir şekilde incelenmelidir.

Çarpışma kutularının enerji sönümleme kapasitelerinin artmasına yönelik, günümüze kadar birçok farklı tasarım yapılmış ve halen de yeni yapılar üzerine çalışmalar devam etmektedir. Yapılan bu tasarımlar, genellikle çarpışma kutularının geometrik özellikleri üzerinedir. Geometrik özellikler değiştirilerek daha iyi enerji sönümleme kabiliyetine sahip çarpışma kutuları imal edilmektedir. Çarpışma kutuları genellikle; dairesel, kare, dikdörtgen ve koniklik açılarına sahip ince cidarlı borular şeklinde tasarlanmaktadır.

Bu çalışmada negatif Poisson oranına sahip olan birim hücre mekanizması; içe girintili (Harkati vd., 2017) ve tetra kiral (Grima vd., 2006) olarak adlandırlan tasarımlardan oluşan silindirik ve kare kesite sahip çarpışma kutularınının çarpışma performansları değerlendirilecektir.

\section{Problem Tanımı}

\subsection{Geometrik Parametreler}

Poisson oranı birçok mühendislik alanında malzemelerin yapısını belirlemeye yarayan önemli bir mühendislik yaklaşımıdır. Poisson oranı, bir malzemede kuvvetin uygulandığ yöndeki kısalma miktarı ile diğer yöndeki uzama miktarı arasındaki bağıntıdır. Mühendislik alanında kullanılan malzemelerin birçoğu pozitif Poisson oranına sahiptir. Son yıllardaki teknolojik ilerlemeler sayesinde negatif Poisson oranına sahip yapılar üzerine olan ilgi artmaktadır. Negatif Poisson oranına sahip malzemelere "Oksetik (Auxetic)" malzemeler denilmektedir. Oksetik malzemeler negatif Poisson oranı sayesinde sürtünme dayanımı, akustik davranış, enerji emme, kopma dayanımı ve kayma modulü gibi daha iyi mekanik özelliklere sahiptir (Ma vd., 2018).

Şekil 1.' de pozitif ve negatif Poisson oranına sahip yapılar arasındaki fark görülmektedir. Şekil 1.a. ve 1.b.' de pozitif Poisson oranına sahip malzemelerin çeki ve bası etkisi altındaki tepkileri görünürken, Şekil 1.c. ve 1.d.' de negatif poisson oranına sahip malzemelerin tepkisi görülmektedir. Şekil 1.c'de çekilen malzemenin incelmesi beklenirken kalınlaşmakta ve Şekil 1.d' de basınç etkisi altındaki malzeme daralmaktadır.
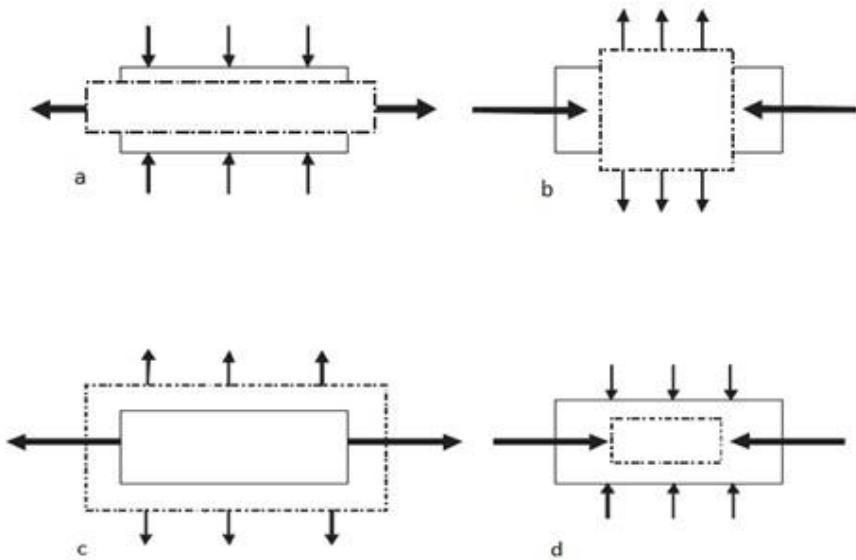

Şekil 1. Negatif ve pozitif Poisson oranına sahip yapıların çeki ve bası etkisi altındaki tepkileri.

Oksetik hücre yapıları, birim hücrelerin geometrik ilişkilerine ve deformasyon mekanizmalarına göre dört ana kategoride incelenebilir; içe girintili (Harkati vd., 2017), faz dönüştürücülü (Liu vd., 2018), sabit mafsal dönüşlü (Grima vd., 2006) ve hiyerarşik yapılar (Lakes, 1993; Wu vd., 2018). Bu çalışmada Şekil 2.a. ve 2.c.'de ki sabit mafsal dönüşlü kategoriye giren "Tetra Kiral (Tetra Chiral) ile Şekil 2.b. ve 2.d.'de ki girintili kategoriye giren "İçe Girintili (Re-entrant) yapılardan yararlanılarak tasarlanmış çarpışma kutuları üzerine çalışılacaktır. $\mathrm{Bu}$ yapıların seçilmesindeki nedenler; klasik yapılara göre daha iyi sürtünme dayanımı, yüksek kırılma dayanımı, burkulma direnci, akustik davranış, kopma dayanımı, kayma modülü ve en önemlisi yüksek enerji emme kabiliyetlerinin olmasıdır(Lu vd., 2019).

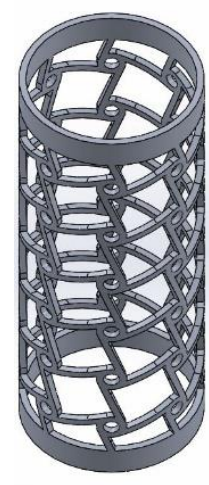

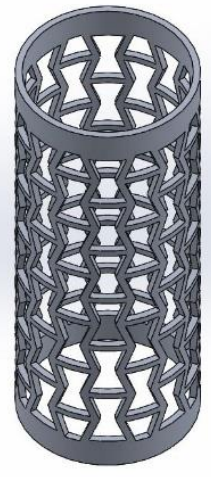

$b$.

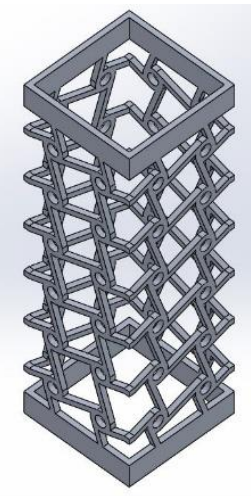

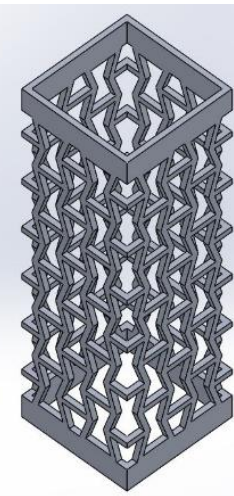

d.
Şekil 2. Tetra Kiral ve İçe Girintili Çarpışma Kutuları (a.Tetra Kiral Silindirik, b.İçe Girintili Silindirik, c.Tetra Kiral Kare, d.İçe Girintili Kare)

Ma ve diğerlerine (2018) ait çalışmada ki tetra kiral yapıya ait geometrik parametrelere (Şekil 3.) bağlı kalınarak eşit ölçülere sahip tetra kiral ve içe girintili çarpışma kutuları tasarlanmıştır. Her bir yapının birim hücresini belirleyen geometrik ölçüler ve tüp sınır ölçüleri aynı değerleri almıştır. 

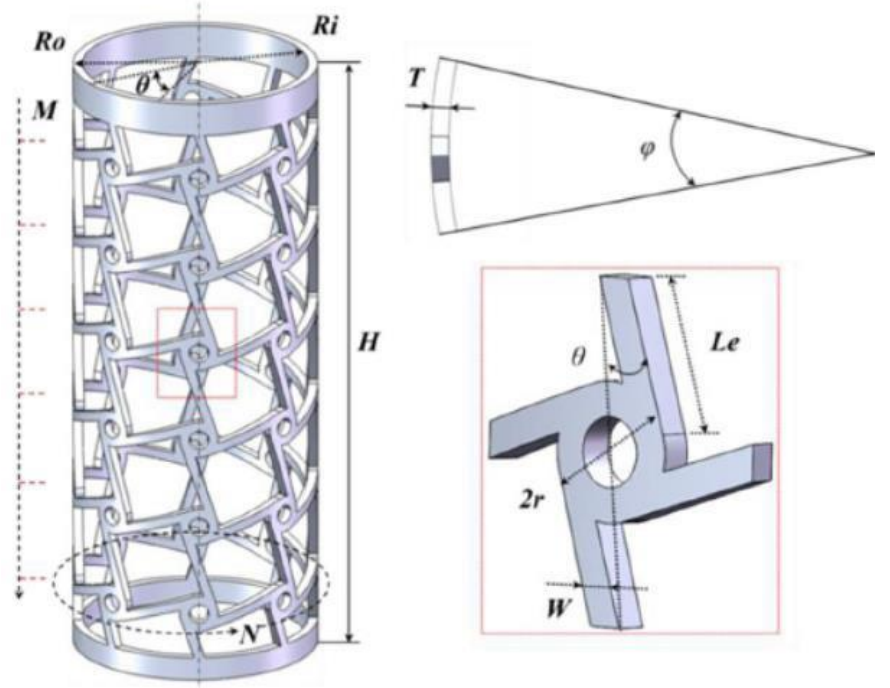

Şekil 3. Tetra Kiral Tüp Geomtrik Parametreler

Tetra kiral çarpışma kutusunun sahip olduğu geometrik parametreler aşağıda sunulmuştur:

- $\quad w=2 \mathrm{~mm}$ (Kiriş genişliği)

- $\quad L e=8.6 \mathrm{~mm}$ (Kiriş kolu uzunluğu)

- $\quad r=4 \mathrm{~mm}$ (Rijit düğüm dls yarı çapl)

- $T=2 \mathrm{~mm}$ (Tüp kalınlı̆̆g )

- $\theta=0.33 \mathrm{rad}$ (Kiriş kolu eksenel yönler arasında ki açı)

- $\quad N=8$ (Cevresel birim hücre sayIsI)

- $\quad M=6$ (Eksenel birim hücre sayIsI)

- $R i=48 \mathrm{~mm}$ (Tüp iç yarıçapı)

- $R o=52 \mathrm{~mm}$ (Tüp dis yarıçapı)

- $\quad H=130 \mathrm{~mm}$ (Tüp yüksekliği)

\subsection{Analiz Gereksinimleri}

Bu dört ayrı silindirik ve kare çarpışma kutularının çarpışma performansını incelemek için sonlu elemanlar yazılımı LS-DYNA kullanılacaktır. Çarpışma kutularının tasarımında kullanılacak olan malzemelerin mekanik özelliklerini belirlemek için çekme testi ve yarı-statik çarpışma analizlerini doğulamak için basma testi ihtiyacı duyulmuştur.

\section{3. Çarpışma Performansı Metrikleri}

Sonlu elemanlar analizi doğrulamasından sonra yapılacak çarpışma analizleri sonuçlarına göre dört farklı yapıdaki çarpışma kutularının performansları belirlemek için aşağıda açıklamaları yapılmış olan çarpışma performansı metrikleri kullanılacaktır (Wu vd., 2016; Acar vd., 2019).

\subsubsection{Toplam Sönümlenen Enerji}

Toplam sönümlenen enerji (Energy Absorption - EA), çarpışma sırasında ortaya çıkan enerjinin yaptığı iş olarak tanımlanabilir. Kuvvet - yer değiştirme grafiğinin altında kalan alan, yani eşitlik (1) kullanılarak hesaplanabilir.

$E A(d)=\int_{0}^{d} F(x) d x$

\subsubsection{Ortalama Ezilme Kuvveti}

Ortalama ezilme kuvveti (Mean Crushing Force - MCF), eşitlik (2) de gösterildiği gibi çarpışma anında sönümlenen toplam enerijinin toplam yer değiştirmeye bölünmesiyle hesaplanan ortalama kuvvettir.

$M C F(d)=\frac{E A(d)}{d}$

\subsection{3. Özgül Enerji Emilimi}

Özgül enerji emilimi (Specific Energy Absorption - SEA), toplam sönümlenen enerjinin yapısal kütleye $(\mathrm{m})$ bölümü ile elde edilen, birim malzemenin enerji sönümleme kabiliyetini ölçmek için kullanılan önemli bir kriterdir (bkz. eşitlik (3)). Yüksek SEA değeri daha yüksek enerji sönümleme kabiliyetini ifade eder.

$S E A=\frac{E A}{m}$

\subsubsection{Tepe Ezilme Kuvveti}

Tepe ezilme kuvveti (Peak Crushing Force - PCF), araç içine gelen tepe kuvvetlerinin en az seviyede olması için ideal bir enerji sönümleyici için minimum seyiyede olmalıdır.

\subsubsection{Ezilme Yükü Verimliliği}

Ezilme yükü verimliliği ( Crash Load Efficiency - CLE), eşitlik (4) te belirtildiği gibi ortalama çarpışma kuvvetinin, tepe ezilme kuvveti değerine bölümü ile elde edilen ve enerji sönümleyiciler için yüksek (Song vd., 2013) CLE değerinin tercih edildiği diğer önemli bir çarpışma metriğidir.

$C L E=\frac{M C F}{P C F}$

\section{3. Çözüm Metodu}

\subsection{Malzeme Mekanik Özellikleri}

$\mathrm{Bu}$ çalışmada, çarpışma kutusu tasarımında 6061-T6 Alüminyum malzeme kullanılmıştır. Sonlu elemanlar analizinde kullanılacak malzeme kartı mekanik özelliklerini elde etmek için standart test metodu ASTM-E8 göre Şekil 4.' deki ölçülere ait üç adet test numunesi hazırlanmıştır. Test numuneleri, kimyasal ve mekanik özelliklerinin bozulmaması için $\mathrm{CNC}$ su jeti makinesinde hazırlanmıştır.

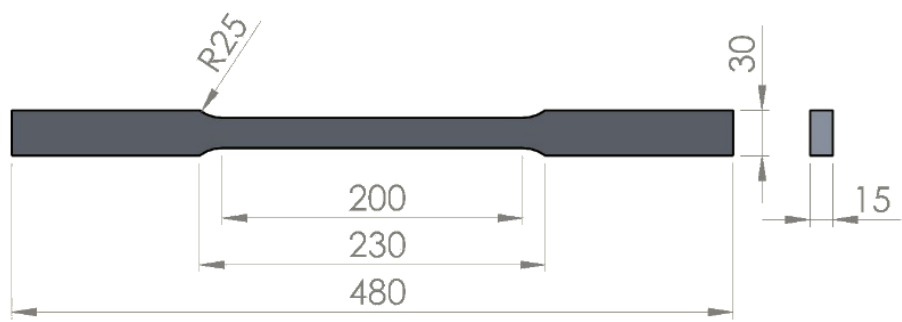

Şekil 4. 6061-T6 çekme numunesi geometrik ölçüleri.

Çekme testleri TOBB ETÜ Mekanik Laboratuvarında bulunan Instron $600 \mathrm{kN}$ kapasiteli universal test makinesinde yapılmıştır (Şekil 5.). Çekme hızı standartlarda belirtildiği gibi 5 $\mathrm{mm} / \mathrm{dk}$ alınmıştır. Çekme testinden elde edilen kuvvet yer değiştirme verilerine göre hesaplanan 6061-T6 malzeme mekanik özelikleri Tablo 1.' de, gerilme - gerinim grafiği Grafik 1.' de görülmektedir. 
Tablo 1. 6061-T6 Alüminyum Mekanik Özellikleri

\begin{tabular}{|c|c|c|c|}
\hline $\begin{array}{l}\text { Yoğunluk } \\
\left(\mathrm{kg} / \mathrm{mm}^{3}\right)\end{array}$ & $\begin{array}{l}\text { Poisson } \\
\text { Oranı }\end{array}$ & $\begin{array}{l}\text { Elastisite } \\
\text { Modülü }(\mathrm{GPa})\end{array}$ & $\begin{array}{l}\text { Akma Dayanımı } \\
(\mathrm{GPa})\end{array}$ \\
\hline $2,7 \times 10^{-6}$ & 0,33 & 68,85 & 0,2845 \\
\hline
\end{tabular}

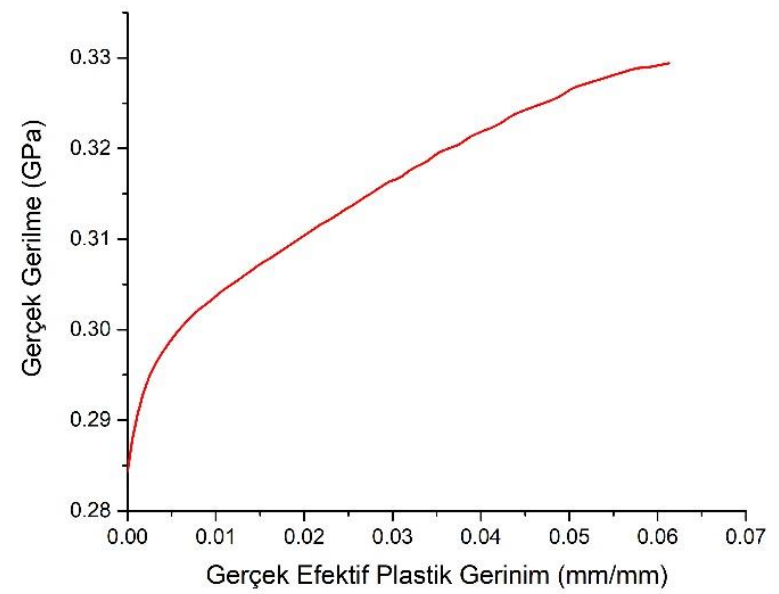

Grafik 1. 6061-T6 Gerilme-Gerinim Grafiği

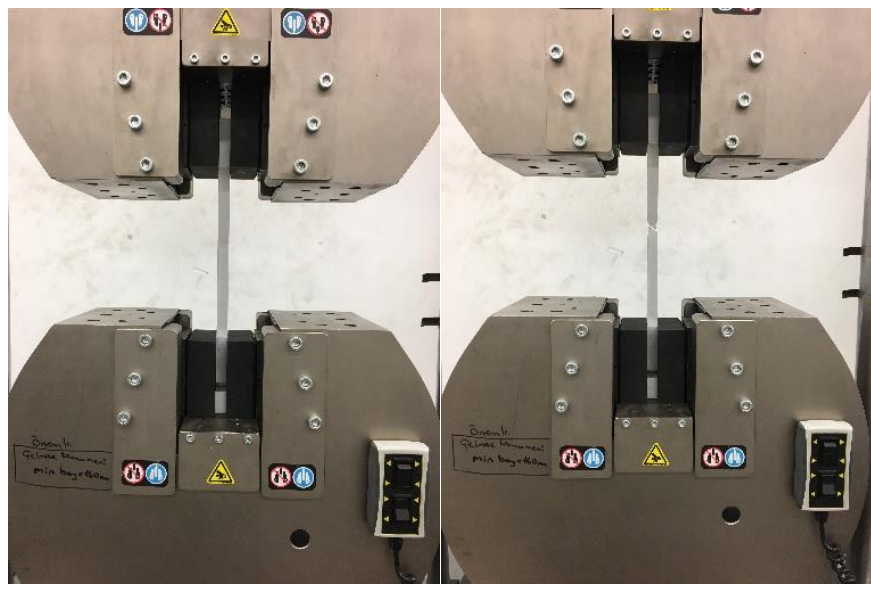

a. Çekme testi öncesi. b. Kırllma sonrast.

Şekil 5. Universal test maknesi düzeneği.

\section{2. Çarpışma Analizi}

\subsubsection{Basma Testleri Doğrulaması}

Çarpışma kutularının yarı-statik çarpışma analizlerini doğrulayabilmek için çekme numunelerinin hazırlandığ1 $15 \mathrm{~mm}$ kalınlığındaki plakadan Şekil 6.a.'daki tertra kiral ve Şekil 6.b.' deki içe girintili plakalar su jetinde hazırlanmıştır. Basma hızının $2 \mathrm{~mm} / \mathrm{dk}$ alındığ 1 testler $600 \mathrm{kN}$ kapasiteli Instron universal test makinesinde yapılmıştır. Sonlu elemanlar analizinin doğrulaması için basma testinden çıktı olarak kuvvet - deplasman verileri elde edilmiştir.

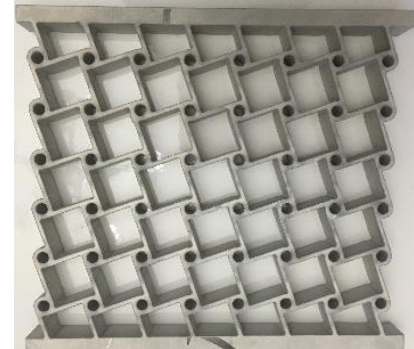

a. Tetra kiral plaka.

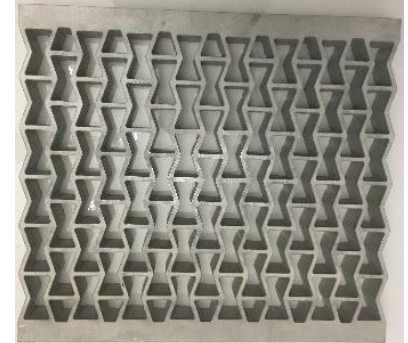

b. Içe girintili plaka.
Şekil 6. Validasyon plakaları.

Ls-Dyna analizi ön hazırlığı için katı modeller hazırlandıktan sonra HyperMesh yazılımı kullanılarak sonlu elemanlar çözüm ağları (Mesh) oluşturulmuştur. Geometrinin karmaşık yapısı nedeni ile mesh ağları oluşturulmadan önce her iki yapı içinde çözüm ağ1 geometrisi hazırlanmıştır (Şekil. 7 ve Şekil. 8). Bu yaklaşım daha sonra yapılacak olan dört farklı çarpışma kutusunun çözüm ağı ön hazırlığında da kulanılacaktır. $0.5 \mathrm{~mm}$ mesh boyutu kulanılarak her iki yapının da çözüm ağı modelleri hazırlanmıştır.

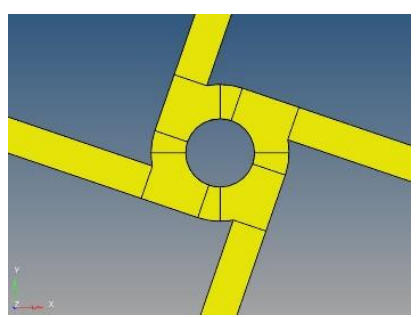

a. Çözüm ă̆ı ön hazırlık.

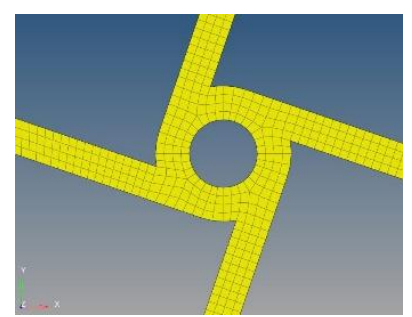

b. Çözüm ă̆l modeli.
Şekil 7. Tetra kiral plaka çözüm ăğ modeli.

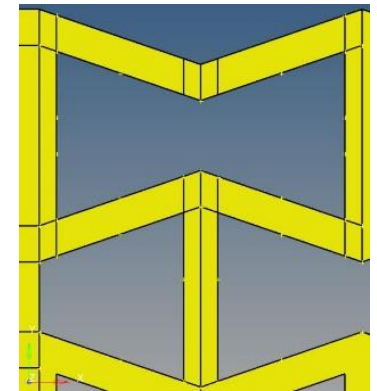

a. Çözüm ă̆ı ön hazırlık. b. Çözüm ă̆ model.

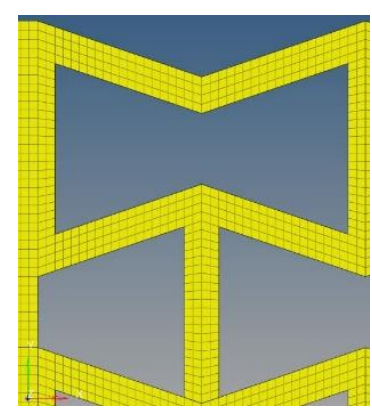

Şekil 8. İçe girintili çözüm ă̆ modeli.

Çözüm ağı modelleri hazırlandıktan sonra Ls-Prepost yazılımında plakaların malzeme kartları, sınır koşulları ve diğer gerekli analiz girdileri hazırlanmıştır. Sonlu elemanlar analizi doğrulaması için hazırlanan Şekil 9. ve Şekil 10.'daki görsellerden de görüldüğü üzere yapılarda maksimum deformasyonların oluştuğu bölgeler benzerdir. Grafik 2.'de gösterilmiş olan kuvvet-deplasman grafiğinde $60 \mathrm{~mm}$ lik yer değiştirme sonucu elde edilen veriler yakın sonuç göstermektedir, aynı zamanda Tablo 2.'den görüldüğü üzere EA, MCF, SEA, PCF ve CLE' düşük hata oranları ile sonlu elemanlar analizinin doğruluğunu kanıtlar niteliktedir. 
European Journal of Science and Technology
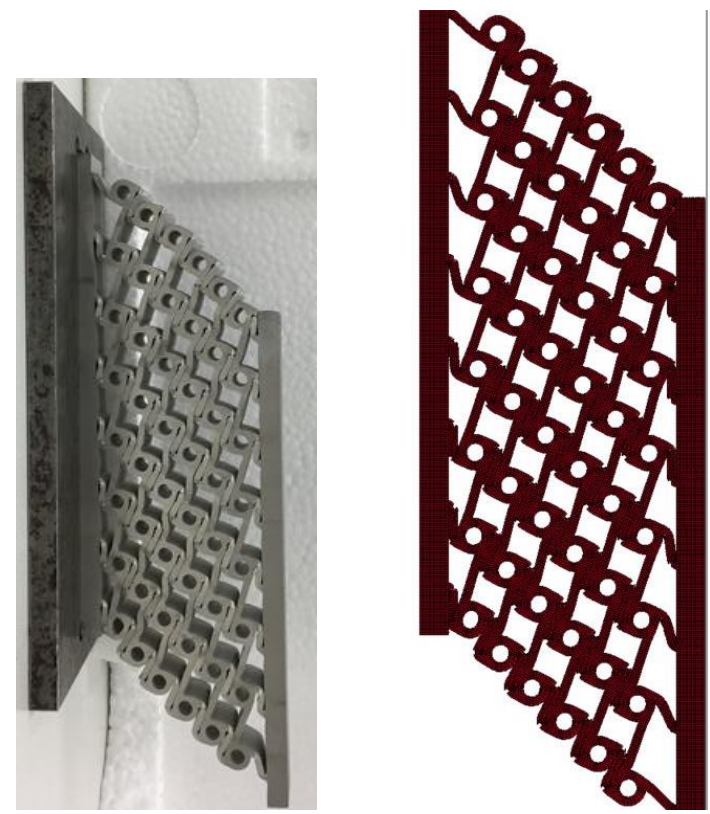

Şekil 9. Tetra kiral plate test ve analiz sonuç görselleri.

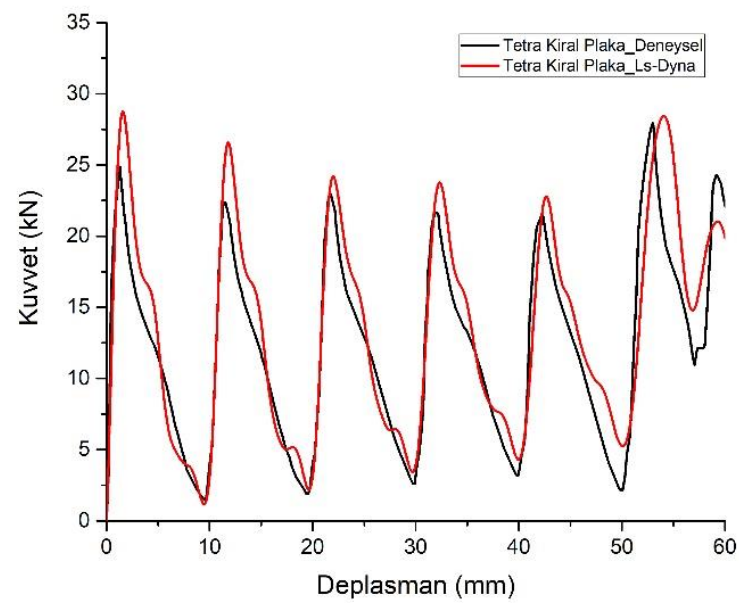

Grafik 2. Tetra kiral plaka kuvvet-yer değiștirme grafiği.

Tablo 2.Tetra kiral plaka çarpışma performansı metrikleri.

\begin{tabular}{|l|l|l|l|l|l|}
\hline & $\begin{array}{l}\text { EA } \\
(\mathbf{k J})\end{array}$ & $\begin{array}{l}\text { SEA } \\
(\mathbf{k J} / \mathbf{k g})\end{array}$ & $\begin{array}{l}\text { PCF } \\
(\mathbf{k N})\end{array}$ & $\begin{array}{l}\text { MCF } \\
(\mathbf{k N})\end{array}$ & $\mathbf{C L E}$ \\
\hline Deneysel & 0,7312 & 3,132 & 27,92 & 12,19 & 0,44 \\
\hline Ls-Dyna & 0,8059 & 3,465 & 28,76 & 13,43 & 0,46 \\
\hline
\end{tabular}
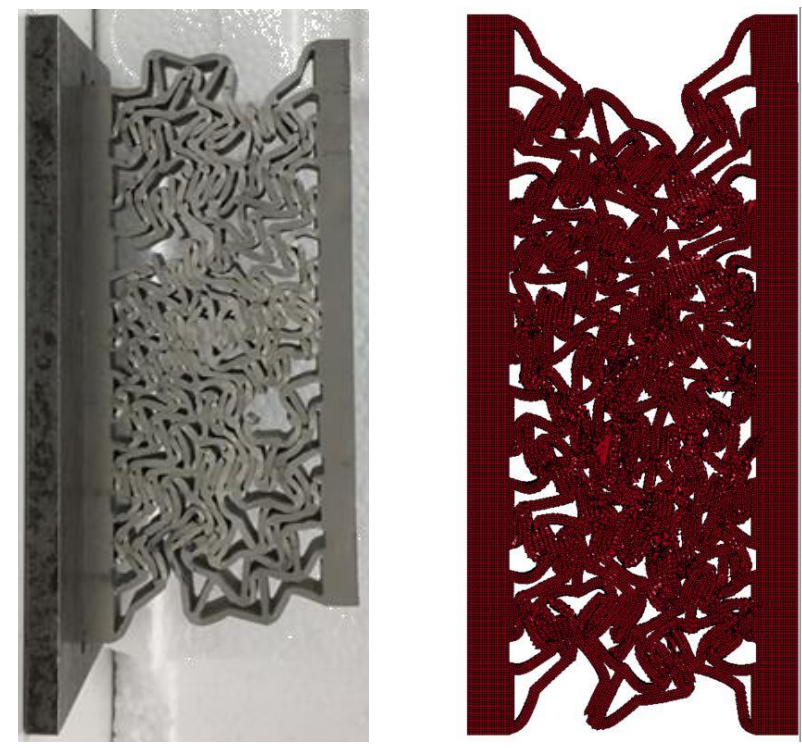

Şekil 10. Içe girintili plaka test ve analiz sonuç görselleri

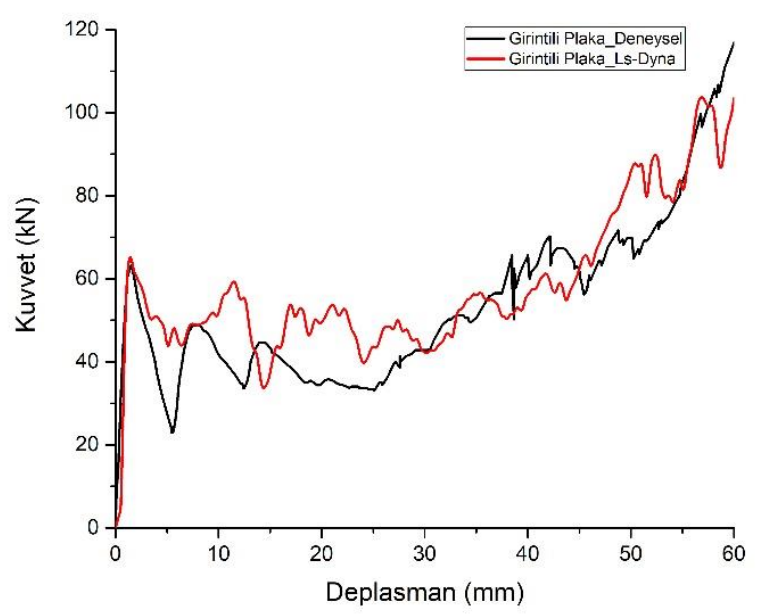

Grafik 3. İ̧e girintili plaka kuvvet - yer değiştirme grafiği.

Tablo 3. İ̧e girintili plaka çarpışma performansı metrikleri.

\begin{tabular}{|l|l|l|l|l|l|}
\hline & $\begin{array}{l}\text { EA } \\
(\mathbf{k J})\end{array}$ & $\begin{array}{l}\text { SEA } \\
(\mathbf{k J} / \mathbf{k g})\end{array}$ & $\begin{array}{l}\text { PCF } \\
(\mathbf{k N})\end{array}$ & $\begin{array}{l}\text { MCF } \\
(\mathbf{k N})\end{array}$ & $\mathbf{C L E}$ \\
\hline Deneysel & 3,231 & 10,15 & 116,84 & 53,88 & 0,46 \\
\hline Ls-Dyna & 3,495 & 10,98 & 103,69 & 58,25 & 0,56 \\
\hline
\end{tabular}




\subsection{2. Çarpışma Kutuları Analizleri}

Tetra kiral ve içe girintili tasarımlardan oluşan kare ve silindirik kesite sahip çarpışma kutularının katı modelleri SolidWorks CAD yazılımı kullanılarak modellenmiştir. Uygun ağ boyutunu belirlemek için iç enerjinin ağ boyutuna (Tanlak, 2018) göre değişimine (Grafik 4.) bakılmış; 0,45 mm ile 0,40 $\mathrm{mm}$ ağ boyutu arasında yakınsama kaydedildiği belirlenmiş ve hesaplama maliyeti açısından daha kısa çözüm süresi veren 0,45 $\mathrm{mm}$ ağ boyutu uygun bulunmuştur. Bunun üzerine, daha önce Bölüm 3.1.'de belirtilmiş olan yaklaşım ile HyperMesh programı kullanılarak ağ modelleri oluşturulmuştur.

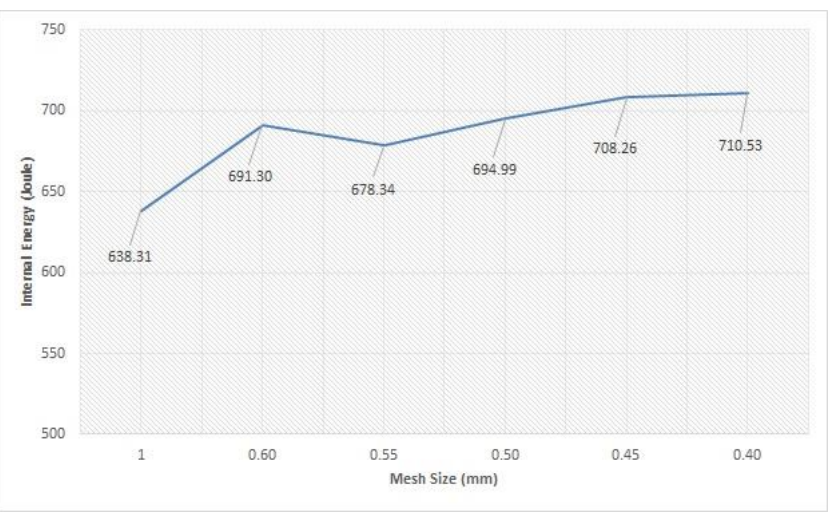

Grafik 4. Ăg yakınsama analizi.

Çarpışma simülasyonunda kullanılacak malzeme özellikleri, sınır koşulları ve diğer girdiler Ls-Prepost yazılımı ile oluşturulmuştur (Acar vd., 2019). Şekil 11.'de görüldüğü gibi; çarpışma kutusu malzemesi olarak "MAT_24 Piecewise Linear Plasticity" malzeme kartı seçilmiştir, malzeme kartı özellikleri için çekme testinden elde edilen verilerden yararlanılmıştır. Hareketli sert plaka için, deforme olmayan "MAT_20 Rigid" malzeme kartı seçilmiştir. Validasyon test düzeneğinde olduğu gibi yap1 alt yüzeyinden " $S P C$ (Single Point Constraint)" kartı ile sabitlenmiştir. Hareketli sert plakaya "BPM (Boundary Prescribed Motion) " ile çarpışma kutusu üst yüzeyi doğrultusuna $2 \mathrm{~mm} / \mathrm{ms} \mathrm{hız} \mathrm{ile} 35 \mathrm{~ms}$ boyunca sabit hız uygulanmıştır. Dört çarpışma kutusu için de aynı yöntem uygulanmış ve çarpışma performansı metrikleri hesaplanmıştır.

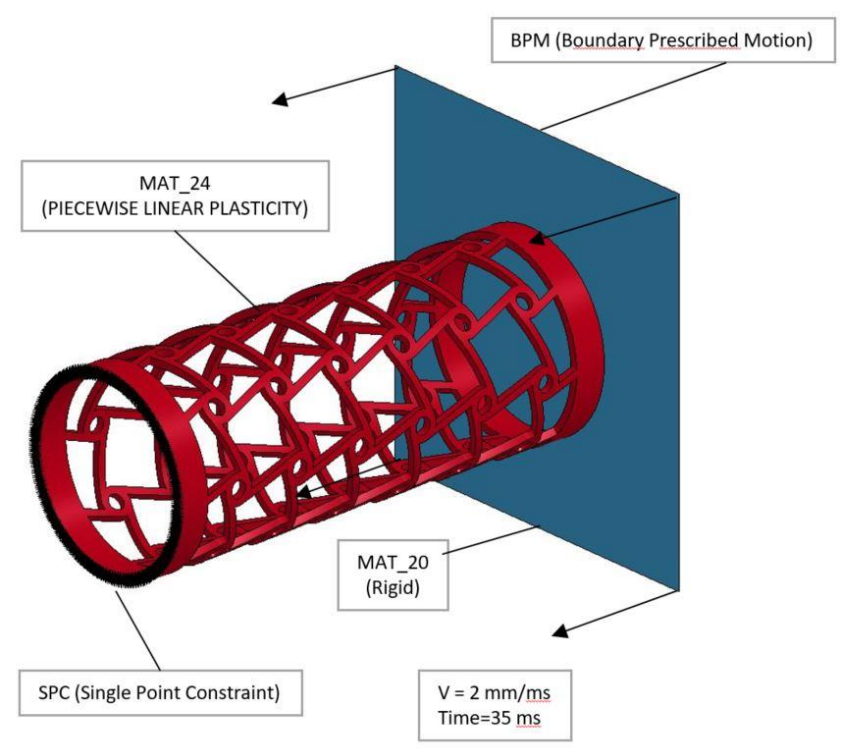

\subsubsection{Analiz Sonuçları}

Tetra kiral ve içe girintili tasarımların silindirik ve kare kesitine sahip çarpışma kutularına ait ağ özellikleri ve kütle bilgileri Tablo 4.'te gösterilmiş olup, aynı geometrik parametre değerleri ile modellendiğinde içe girintili yapıların daha ağır olduğu görülmektedir.

Tablo 4. Çarpışma kutuları ă̆ ve kütle özellikleri.

\begin{tabular}{|c|c|c|c|}
\hline & $\begin{array}{l}\text { Düğüm } \\
\text { Sayıs1 }\end{array}$ & $\begin{array}{l}\text { A } \breve{g} \\
\text { Eleman } \\
\text { Sayis1 }\end{array}$ & $\begin{array}{l}\text { Kütle } \\
\text { (gr) }\end{array}$ \\
\hline $\begin{array}{l}\text { Tetra Kiral } \\
\text { Silindirik Tüp }\end{array}$ & 163.400 & 112.832 & 37,45 \\
\hline $\begin{array}{l}\text { İçe Girintili } \\
\text { Silindirik Tüp }\end{array}$ & 227.120 & 157.824 & 46,87 \\
\hline $\begin{array}{l}\text { Tetra Kiral } \\
\text { Kare Tüp }\end{array}$ & 161.720 & 111.360 & 37,21 \\
\hline $\begin{array}{l}\text { İçe Girintili } \\
\text { Kare Tüp }\end{array}$ & 395.241 & 135.040 & 46,24 \\
\hline
\end{tabular}

$60 \mathrm{~mm}$ yarı statik basma analizi sonucu yapılan analizlere ait kuvvet-deplasman grafikleri Grafik 5,,6.,7. ve 8. de sunulmuştur. $\mathrm{Bu}$ grafiklerden elde edilen çarpışma performansı metrikleri ise Tablo 5.' de görülmektedir. Tetra kiral yapılar, eksenel yükleme esnasında yapının geometrik doğasından dolayı ortaya çıkan sıkıştırma-dönme (Ma vd., 2018) ilişkisi sayesinde aynı periyodlarda tepki olarak tepe kuvvetleri vermektedir. Buna karşın girintili yapı ise eksenel kuvvet uygulandığında ilk tepe kuvvetinden sonra iç içe büzülerek daha direngen bir davranış göstermiş ve dolayısı ile tepe kuvvet değerleri daha yüksektir.

Tablo 5.Çarpışma kutuları performans metrikleri.

\begin{tabular}{|l|l|l|l|l|l|}
\hline & $\begin{array}{l}\text { EA } \\
(\mathrm{kJ})\end{array}$ & $\begin{array}{l}\text { SEA } \\
(\mathrm{kJ} / \mathrm{kg})\end{array}$ & $\begin{array}{l}\text { PCF } \\
(\mathrm{kN})\end{array}$ & $\begin{array}{l}\text { MCF } \\
(\mathrm{kN})\end{array}$ & CLE \\
\hline $\begin{array}{l}\text { Tetra Kiral } \\
\text { Silindirik Tüp }\end{array}$ & 0,1029 & 2,748 & 3,896 & 1,715 & 0,44 \\
\hline $\begin{array}{l}\text { İçe Girintili } \\
\text { Silindirik Tüp }\end{array}$ & 0,2089 & 4,457 & 8,638 & 3,482 & 0,40 \\
\hline $\begin{array}{l}\text { Tetra Kiral } \\
\text { Kare Tüp }\end{array}$ & 0,0986 & 2,650 & 3,570 & 1,643 & 0,46 \\
\hline $\begin{array}{l}\text { İçe Girintili } \\
\text { Kare Tüp }\end{array}$ & 0,2139 & 4,626 & 8,125 & 3,565 & 0,43 \\
\hline
\end{tabular}




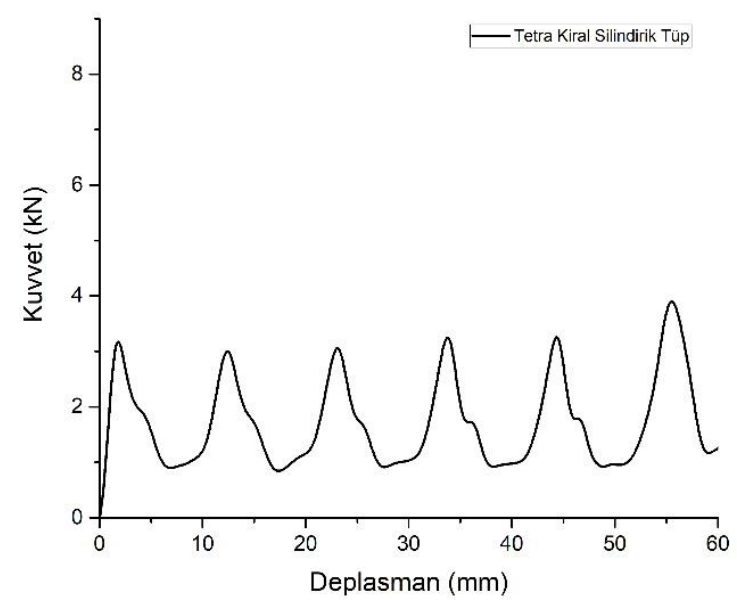

Grafik 5. Tetra kiral silindirik tüp kuvvet - deplasman grafiği.

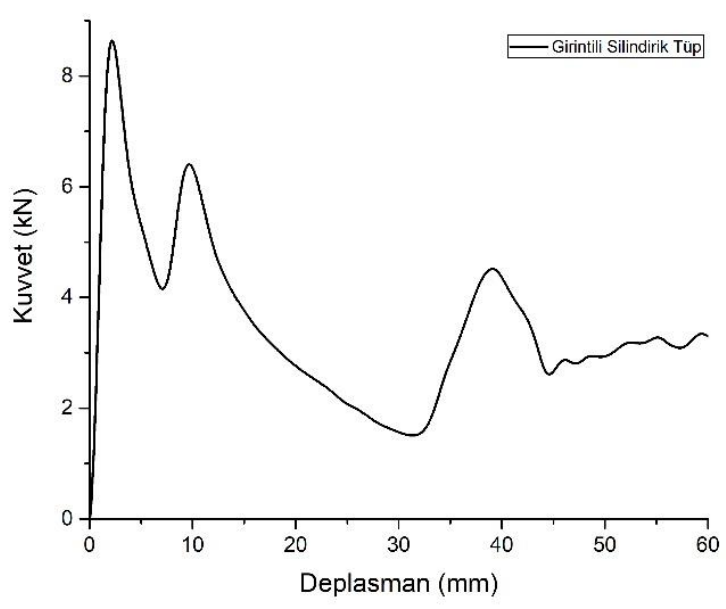

Grafik 6. İçe girintili silindirik tüp kuvvet-deplasman grafiği.

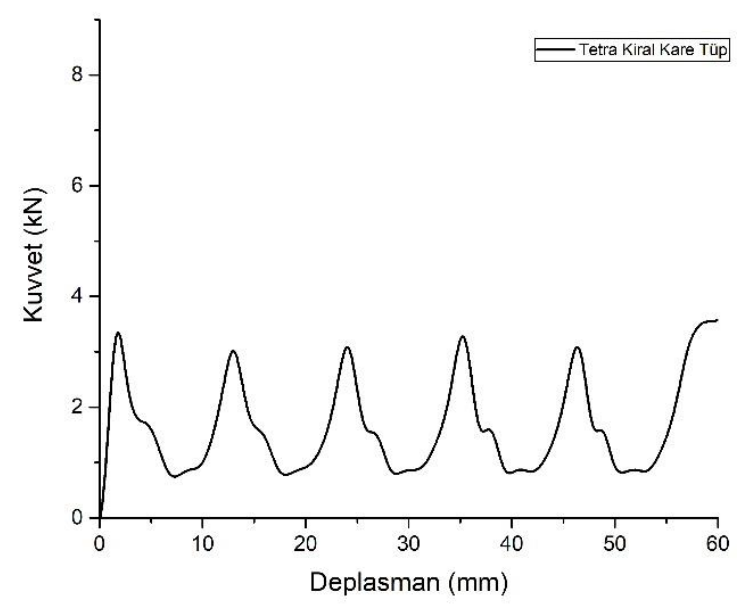

Grafik 7. Tetra kiral kare tüp kuvvet-deplasman grafiği.

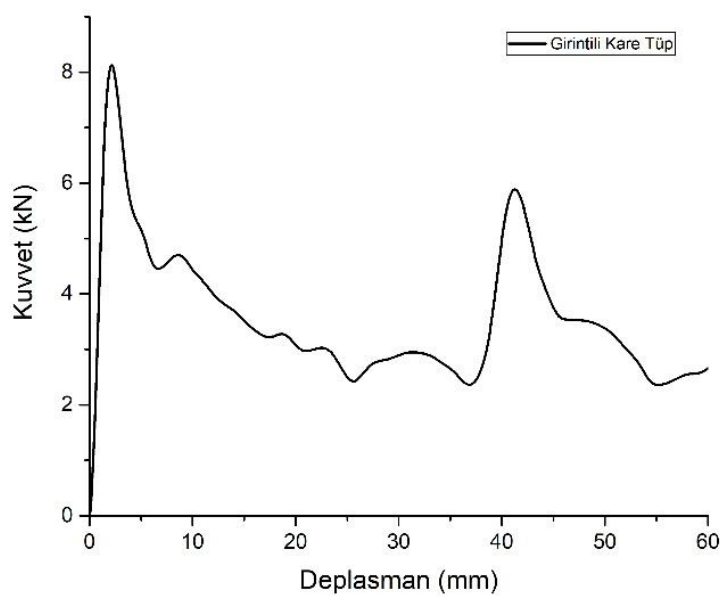

Grafik 8. Içe girintili kare tüp kuvvet - deplasman grafiği.

\section{Sonuç}

Bu çalışmada, negatif Poisson oranına sahip yapılardan olan "Tetra Kiral" ve "İçe Girintili" tasarımlar ele alınmış, bu tasarımlardan silindir ve kare kesite sahip çarpışma kutuları oluşturularak çarpışma performansları incelenmiştir. Elde edilen analiz sonuçlarına göre aşağıdaki çıkarımlar yapılmıştır:

- Toplam Sönümlenen Enerji çarpışma metriği göz önüne alındığında, ezilme sırasında daha direngen bir davranış gösteren “Íçe Girintili Kare Çarpışma Kutusu” 0,2139 kJ enerji sönümleme miktarı ile diğerlerinden fazla enerji sönümleme yapmıştır.

- Verimli bir darbe sönümleyiciden oldukça hafif olması beklenir. Bunu ölçmek için kullanıan birim kütle başına sönümlenen enerji miktarı olan Özgül Enerji Emilimi dikkate alındığında "İçe Girintili Kare Çarpışma Kutusu” 4,626 kJ/kg'l1k bir performans ile üstün bir davranış göstermiştir.

- Bir çarpışma sırasında ortaya çıkan kuvvete darbe sönümleyicinin tepki olarak gösterdiği kuvvet, direkt olarak araç içine dolayısıyla yolculara etki etmektedir. Yolcular için hayati önem taşıyan Tepe Ezilme Kuvveti mümkün olduğu kadar düşük olmalıdır. Kuvvet - dönme özelliği sayesinde darbe sönümleyici üzerine gelen kuvvete yumuşak bir tepki gösteren "Tetra Kiral Kare Çarpışma Kutusu” 3,570 kN bir tepkiyle en düşük PCF değerini vermiştir.

- Araç içine tesir eden kuvvetlerin ortalaması olan Ortalama Ezilme Kuvveti değerlendirildiğinde ise bütün yapılar ortalama maksimum tepe kuvvetlerinin yarısı civarında bir kuvvet vermektedir.

- $\quad$ Yüksek performanslı bir sönümleyici için Ezilme Yükü Verimliliği mümkün olduğu kadar yüksek olmalıdır. Bu metrik göz önüne alındığında “Tetra Kiral Kare Çarpışma Kutusu” 0,46 lik bir performans ile diğer yapılara göre daha verimli enerji sönümleme davranışı göstermiştir. 
Sunulan çalışma üzerine geleceğe yönelik çalışmalar kurgulanmaktadır. Çalışmada ele alınan çarpışma kutularının geometrik parametrelerinin optimize edilerek daha yüksek performanslı çarpışma kutusu tasarımları elde edilmesi hedeflenmektedir.

\section{Kaynaklar}

Acar, E., Altin, M., Güler, M.A. (2019). Evaluation of various multi-cell design consepts for crashworthiness design of thin-walled aluminium tubes. Thin-Walled Struct. 142:227-235.

Harkati, E., Daoudi, N., Bezazi, A., Haddad, A., Scarpa, F. (2017). In-plane elasticity of a multi re-entrant auxetic honeycomb. Compos Struct. 180:130-9.

Grima, JN., Manicaro, E., Attard, D. (2011). Auxetic behaviour from connected different-sized squares and rectangles. Proc Math Phys Eng Sci. 467:439-58.

Lakes, R. (1993). Materials with structural hierarchy. Nature. 361(6412):511-5.

Liu, J., Qin, H., Liu, L. (2018). Dynamic behaviors of phase transforming cellular structures. Compos Struct. 184:53644.

Lu, Q., Qi, D., Li, Y., Xi, D., Wu, Q. (2019). Impact energy absorption performances of ordinary and hierarchical chiral structures. Thin-Walled Structures. 140:495-505.

Ma, C., Lei, H., Hua, J., Bai, Y., Liang, J., Fang, D. (2018). Experimental and simulation investigation of the reversible bidirectional twisting response of tetra-chiral cylindrical shells. Composite Struct. 203:142-152.

Song, X., Sun, G., Li, G., Gao, W., Li, Q. (2013). Crashworthiness optimization of foam-filled tapered thin-walled structure using multiple surrogate models. Struct Multidisciplinary Optim. 47(2):221-31.

Tanlak, N., P.D. (2014). Shape optimization of thin-walled tubes under high-velocity axial and transverse impact loadings. FBE, Boğaziçi University.

Wu, Q., Gao, Y., Wei, X., Mousanezhad, D., Ma, L., Vaziri, A., et al (2018). Mechanical properties and failure mechanisms of sandwich panels with ultra-lightweight threedimensional hierarchical lattice cores. Int J Solids Struct. 132133:171-87. 